\title{
Population dynamics of Rimapenaeus constrictus (Stimpson, 1874) (Penaeoidea) on the southeastern Brazilian coast: implications for shrimp fishing management from a 5-year study on a bycatch species
}

\author{
ANA ELISA B. LOPES ${ }^{1}$, RAPHAEL C. GRABOWSKI ${ }^{1}$, JOYCE R. GARCIA ${ }^{1}$, ADILSON FRANSOZO ${ }^{1}$, \\ ROGÉRIO C. DA COSTA ${ }^{2}$, KÁTIA A.N. HIROKI ${ }^{3}$ and ANTONIO L. CASTILHO ${ }^{1}$

\begin{abstract}
${ }^{1}$ Universidade Estadual de São Paulo/UNESP, Instituto de Biociências de Botucatu, Departamento de Zoologia, Rua Professor Doutor Antonio Celso Wagner Zanin, s/nº, Distrito de Rubião Júnior, 18618-689 Botucatu, SP, Brazil ${ }^{2}$ Universidade Estadual de São Paulo/UNESP, Faculdade de Ciências, Departamento de Ciências Biológicas, Avenida Luiz Edmundo Carrijo Coube, no 14-01, Vargem Limpa, 17033-360 Bauru, SP, Brazil

${ }^{3}$ Universidade Federal do Triângulo Mineiro/UFTM, Instituto de Ciências Exatas, Naturais e Educação, Departamento de Ciências Biológicas, Avenida Doutor Randolfo Borges, 1400, Univerdecidade, 38064-200 Uberaba, MG, Brazil
\end{abstract}

Manuscript received on August 26, 2016; accepted for publication on November 28, 2016.

\begin{abstract}
This is the first study to evaluate in broad spatiotemporal scales the growth parameters and population structure of Rimapenaeus constrictus, a barely damaged species composing the bycatch from shrimp fishing in the Western Atlantic. The abundance and size-class frequency distribution, growth, longevity and sex ratio were evaluated from monthly samples obtained in the northern littoral of São Paulo state from Jan/1998 to Jun/2003. We measured 5,812 individuals in which the sex ratio was skewed toward females; this was more evident in size classes greater than $10 \mathrm{~mm}$ in CL (carapace length) (binomial test, $\mathrm{p}<0.05$ ). We selected 16 growth cohorts of females, and 8 of males, the majority consisting of younger individual cohorts excluded from the fisheries closure period. Growth estimates resulted in a $\mathrm{CL}_{\infty}$ of $17.42 \mathrm{~mm}$, a growth coefficient of 0.008 and a longevity of 579 days (1.60 year) for females, as well as a $\mathrm{CL}_{\infty}$ of 16.3 $\mathrm{mm}$, a growth coefficient of 0.01 and a longevity of 425 days (1.17 year) for males. Our results provide information of incontestable relevance to our knowledge of fishing management. We therefore strongly recommend that the fisheries closure period be changed to protect this species' recruitment period and consequently its adult individuals.
\end{abstract}

Key words: Fisheries biology, latitudinal variation, recruitment cohorts, roughneck shrimp, stock conservation.

\section{INTRODUCTION}

Crustacean fisheries production has been declining throughout the southeastern Brazilian Coast, mainly in the Ubatuba region, which within a

Correspondence to: Ana Elisa Bielert Lopes

E-mail: anaelisa_lopes@hotmail.com 10-year period (2005-2015) has shown a 64\% of reduction in biomass landings (Instituto de Pesca, São Paulo: www.pesca.sp.gov.br). Commercial fishery trawling in the Brazilian Southeastern region targets species such as Farfantepenaeus brasiliensis (Latreille, 1817), F. paulensis (Pérez- 
Farfante 1967), Litopenaeus schmitti (Burkenroad, 1938), Xiphopenaeus kroyeri (Heller, 1862), Artemesia longinaris Spence Bate, 1888 and Pleoticus muelleri (Spence Bate, 1888) (D’Incao et al. 2002). In Brazilian Southeastern coast, the use of motor boats for shrimp trawling from March $1^{\text {st }}$ to May $31^{\text {st }}$ is forbidden by the Brazilian Institute of Environment and Natural Renewable Resources (IBAMA 2016). During this season (the fisheries closure period), fishermen are prohibited from using such gear to capture economically marketable shrimp species or to transport, stock or commercialize these animals. This measure aims to protect their regular population structure, reproduction and recruitment period (normative instruction available at: www.ibama.gov.br).

Trawling activity uses non-selective fishing gear, i.e., along with the target species, many nontarget organisms (bycatch fauna) are incidentally caught. According to Dias Neto (2011), a minority of the bycatch fauna is landed and is locally commercialized (often at very low prices), on the other hand, most is discarded back to the sea already dead due to their negligible commercial value. On average, in a trawl to obtain tropical shrimp, the captured bycatch is 3 to 15 times larger than the captured target species (FAO 2015). The ecological impacts resulting from shrimp fishing are still poorly understood, but are known to be considerable. One of the main effects of the bycatch capture on the ecosystem is the alteration in the species composition and/or in the stock size of the bycatch species (Dias Neto 2011). Theoretically, species with no economic value (bycatch), such as Rimapenaeus constrictus (Stimpson, 1874), are protected by the fisheries closure period as well, since the bycatch and economically important species are not being captured during this period.

Rimapenaeus constrictus exhibits a broad geographical distribution ranging from Nova Scotia (Canada) to Santa Catarina (Brazil). This species is among those most often accidentally caught during fishery activities, and due to its small size, it is not commercially exploited. However, it plays an important ecological role as part of the trophic web chain within its habitat range (Pérez-Farfante and Kensley 1997, Costa and Fransozo 2004b).

The biological knowledge about species and estimates of their population parameters (size class distributions, growth rates, sex ratios, etc.) are highly relevant to provide essential information about the management of fishing resources (GabAlla et al. 1990, Bauer and Rivera Vega 1992, Castilho et al. 2015a). With regard to shrimp growth studies, the most accepted (and consequently most utilized) methodology is the von Bertalanffy (1938) growth model, which estimates the age of an individual of a given body size according to a mathematical equation. This methodology is necessary due to the impossibility of periodic tissue tagging, since crustaceans do not have permanent skeletal structures (Hartnoll 2001, Fonseca and D'Incao 2003, Campos et al. 2011, Castilho et al. 2015b).

However, only a few studies have been undertaken to guide and clarify the basic biology of the population dynamics and life history of this species. In the northern littoral of São Paulo state, Costa and Fransozo (2004a, b) studied its reproductive biology and its abundance and ecological distribution, respectively, and Hiroki et al. (2011) investigated its bathymetric distribution. In the southern littoral of São Paulo, only the study addressing its growth and lifespan carried out by Garcia et al. (2016) is available in a different region. In addition to the studies conducted on the Brazilian coast, Bauer and Lin (1994) evaluated the reproductive and recruitment periods of the congeneric species, Rimapenaeus similis (Smith, 1885 ) and $R$. constrictus, in the Gulf of Mexico.

It is important to point out that to date, no studies have been done concerning growth and longevity of $R$. constrictus in the Ubatuba region or on the northern coast of São Paulo state; thus, this 
is a pioneer study for this approach. It is therefore necessary to strengthen our biological knowledge about the bycatch by obtaining appropriate data. These findings are essential to substantiate the implementation of management and sustainable use measures for marine shrimp fishing along the Brazilian coast, especially since current knowledge is insufficient to make scientifically based decisions (Dias Neto 2011).

On the basis of this scenario, we here describe the population structure and sex ratio and estimate the growth parameters for $R$. constrictus across a wide temporal scale, for 5 years, in Ubatuba in the northern littoral of São Paulo state. Additionally, we tested the hypothesis that such parameters undergo alterations induced by environmental features related to the latitude and compared our results to the studies on $R$. constrictus available to date. For the first time, a growth analysis covers the whole bathymetric distribution of this species on the Brazilian coast, and distinct results can therefore be observed. Thus, we could determine whether the commonly referred to "latitudinal effect paradigm" proposed by Bauer (1992) and Castilho et al. (2007b) is applicable to the growth parameters of the species concerned here, as it was already reported to apply to its reproductive aspects (Costa and Fransozo 2004a). We also verified the applicability of the current fisheries closure period to this species with regard to its functionality for the recruitment observed during the study period.

\section{MATERIALS AND METHODS}

\section{STUDY AREA}

The Ubatuba region presents an extremely indented coastline, resulting in the creation of many bays with particular environmental conditions exhibiting very irregular internal limits that are favorable to the establishment of the local fauna. It is a result of the peculiar characteristics and ecological needs of each species and the consequent development of particular marine faunas (Negreiros-Fransozo et al. 1991).

The main oceanographic feature structuring ecosystems on the southeastern and southern Brazilian continental shelf is the presence of the South Atlantic Central Waters, a water mass characterized by low temperature and salinity (SACW: $\mathrm{T}<18^{\circ} \mathrm{C} ; \mathrm{S}<36$ ) (Pires-Vanin 2001, Soares-Gomes and Pires-Vanin 2003). In addition, the northern coast of São Paulo state is strongly influenced by two other water masses, each showing specific characteristics and distinct models of distribution between summer and winter: Coastal Water (AC: high temperature $\left(>20^{\circ}\right.$ C) and low salinity $[<36]$ ) and Tropical Water (TW: high temperature $\left(>20^{\circ} \mathrm{C}\right)$ and high salinity $\left.[>36]\right)$ (Castro-Filho et al. 1987).

The SACW approaches from the continental shelf in the bottom water layers, reaching the coastal zone and causing the low water temperatures recorded during spring and early summer (minimum values of $15^{\circ} \mathrm{C}$ ). This process creates a thermocline at depths of 10 to $15 \mathrm{~m}$ due to the presence of cold water in the bottom layers of the water column and warm water in the remaining layers (Castro-Filho et al. 1987).

\section{BIOLOGICAL SAMPLING}

Samplings were carried out monthly from Jan/1998 to Jun/2003, with a gap between January 2001 to June 2001, along the northern coast of São Paulo state in the Ubatuba region. Samples were obtained during the day using a shrimp-fishing boat outfitted with double-rig nets (mesh size: $20 \mathrm{~mm}$ knot-toknot in the body and $15 \mathrm{~mm}$ in the cod end). Trawls were extended for two kilometers for 30 minutes each, sampling a total area of $18,000 \mathrm{~m}^{2}$.

Carapace length (CL) was adopted as a standard measurement in this study, corresponding to the linear distance from the post-orbital angle and the posterior margin of the carapace, which 
has been widely used in investigations concerning penaeid shrimps (Castilho et al. 2015a, b). CL size frequencies were distributed in 1-mm classes to each sex, separately. Both were compared by a Kolmogorov-Smirnov two-sample test in which the null hypothesis adopted was that size distribution among sexes did not differ (Castilho et al. 2008a). Recruitment was estimated as the percentage of the population sampled in the lower $25 \%$ of all possible size classes (males + females). Thus, for the purposes of measuring recruitment, all individuals with a CL less than $9.4 \mathrm{~mm}$ were considered recruits (Bauer and Rivera Vega 1992, Castilho et al. 2008a).

\section{SEX RATIO}

Individuals were classified to sex according to the presence of a petasma (males) or a thelycum (females) (Pérez-Farfante 1988). The sex ratio was estimated as the quotient between the number of males and the total number of individuals in the monthly samples. Differences in the expected ratio of 1:1 (males:females) were tested with the binomial test $(\alpha=0.05)$ (Wilson and Hardy 2002, Grabowski et al. 2014).

\section{GROWTH AND LONGEVITY}

Growth and longevity were analyzed separately for each sex according to the von Bertalanffy (1938) growth model and using the methodology purposed by Simões et al. (2013). Modal values were determined for each CL frequency using the software Peakfit 4.0 (Automatic Peak Fitting Detection and Fitting, Method I-Residual, no Data Smoothing) in size classes of $1.0 \mathrm{~mm}$. The models were plotted on a scatter graph vs. age to verify the growth rhythm of the cohorts. Growth parameters $\left(C L_{\infty}\right.$ : asymptotic carapace length; $k$ : growth coefficient (day-1); $t_{0}$ : theoretical age at size 0) were estimated using the SOLVER supplement in Microsoft Excel, which applies the von Bertalanffy growth model: $C L_{t}=C L_{o}[1-\exp$ $\left.k^{(t-t)}\right]$ ( $C L_{t}$ : carapace length at age $\left.\mathrm{t}\right)$. The cohort data were pooled, and the growth parameters estimated. The estimated growth curves for each sex were compared by an $\mathrm{F}$ test $(\mathrm{p}=0.05)$ (Cerrato 1990). Longevity was calculated using the inverse von Bertalanffy growth model with a modification suggested by D'Incao and Fonseca (1999) given by longevity $=0-(1 / \mathrm{k}) \ln \left[1-\left(C L / C L_{\infty}\right)\right]$ (considering $t_{0}=0$, and $\left.C L / C L_{\infty}=0.99\right)$. Cohorts including the modal peaks of recruitment size $(<9.4 \mathrm{~mm} \mathrm{CL})$ were identified as recruitment cohorts, and the age at which individuals become adult was estimated by the equation purposed by King (1995): $t=t_{0}$ $(1 / k) \cdot \ln \left(1-\left(C L / C L_{\infty}\right)\right.$.

\section{RESULTS}

\section{POPULATION STRUCTURE}

During this study 5,812 individuals were sampled, including 1,458 males and 4,354 females. Carapace length varied from 4.2 to $17.9 \mathrm{~mm}$ in males (mean: $9.21 \mathrm{~mm} \pm 1.31 \mathrm{SD}$ [standard deviation]) and from 3.4 to $19.2 \mathrm{~mm}$ in females (mean: $12.1 \mathrm{~mm} \pm 2.31$ $\mathrm{SD})$. Males were more abundant in the 5 to $9 \mathrm{~mm}$ size classes and females, from 10 to $19 \mathrm{~mm}$, with a peak abundance observed at $12 \mathrm{~mm}$ (Figure 1). The size class distributions for males and females showed a statistically significant difference (Kolmogorov-Smirnov, $\mathrm{d}_{\max }=0.61 ; \mathrm{p}=0.04$ ).

\section{SEX RATIO}

Throughout the sampling period, we observed a female-biased sex ratio (binomial test, $\mathrm{p}<0.05$ ), as they were more abundant compared to the number of males (Figure 2).

From the size class distribution for adult individuals, it was possible to observe a male-biased sex ratio in the smaller size classes $(5-9 \mathrm{~mm})$. From $10 \mathrm{~mm}$ on, the sex ratio was exclusively female biased (Figure 3). 


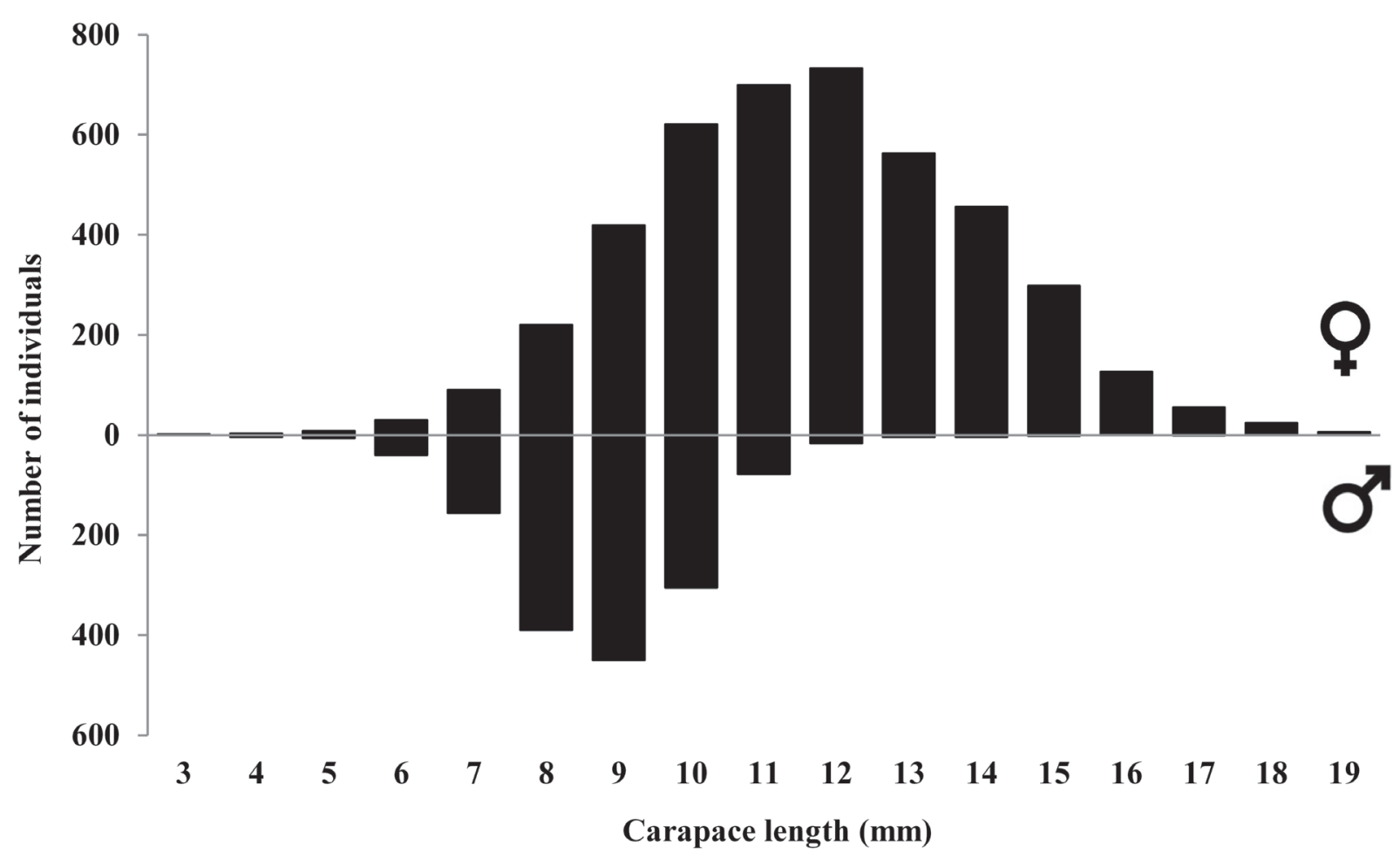

Figure 1 - Rimapenaeus constrictus. Size class distributions of males and females for samples obtained from January 1998 to June 2003 at the northern littoral of São Paulo state.

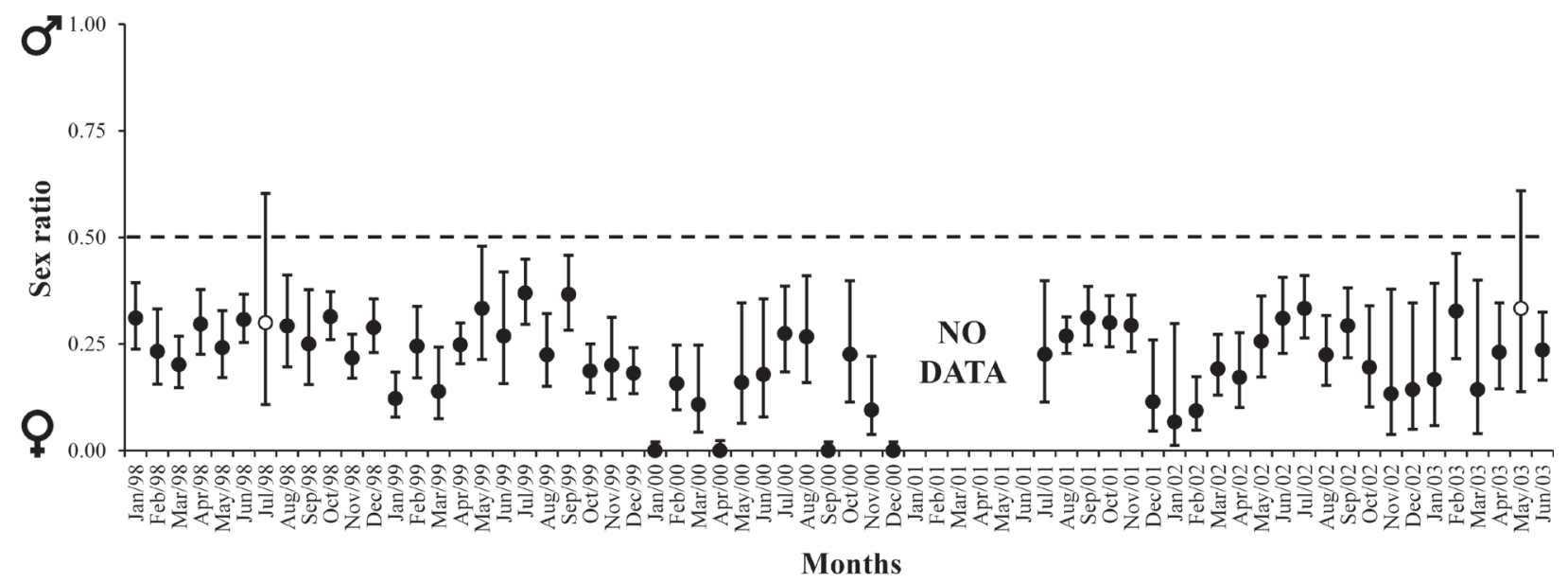

Figure 2 - Rimapenaeus constrictus. Monthly sex ratio (estimate \pm standard error) for samples from January 1998 to June 2003 from the northern littoral of São Paulo state. Black circles indicate a significant deviation from a 1:1 (M:F) sex ratio (binomial test, $\mathrm{p}<0.05)$. 


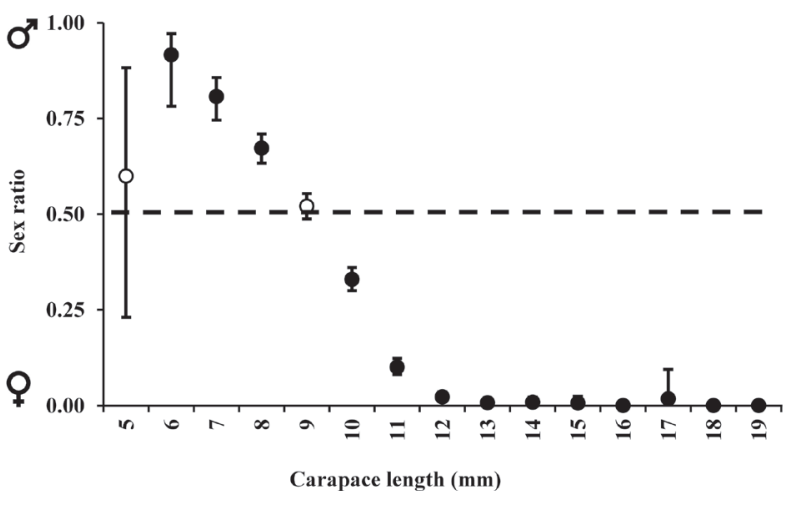

Figure 3 - Rimapenaeus constrictus. Sex ratio observed among the size classes (estimate \pm standard error) for individuals sampled from January 1998 to June 2003 from the northern littoral of São Paulo state. Black circles indicate a significant deviation from a 1:1 (M:F) sex ratio (binomial test, $\mathrm{p}<0.05)$.

\section{GROWTH AND LONGEVITY}

We identified 16 female and 8 male cohorts (Figures 4 and 5). For males, only 2 recruitment cohorts $(<9.4 \mathrm{~mm} \mathrm{CL})$ (cohorts 3 and 7 ) were set in the fisheries closure periods from the time of their emergence until reaching adult size. This condition is even more critical for females because only 3 recruitment cohorts (cohorts 5, 15 and 16) were set in the fisheries closure periods from their emergence until reaching adult size. Moreover, the majority of the remaining cohorts including recruitment sizes were identified in December and February (females: cohorts 2, 6 and 10; males: cohorts 1, 4 and 8). Estimates of the growth parameters resulted in $C L_{\infty}: 17.42 \mathrm{~mm}, k: 0.008$ and $t_{0}:-1.50$ days for females, and $C L_{\infty}: 16.3 \mathrm{~mm}, k$ : 0.01 and $t_{0}:-0.60$ days for males (Figures 6 and 7). From the growth curves, longevity was estimated as 579 days ( 1.60 year) for females and 425 days (1.17 year) for males. Growth curves for males and females showed a significant difference through an $\mathrm{F}$ test $\left(\mathrm{F}_{\text {critical }}=2.688<\mathrm{F}_{\text {calculated }}=4.124 ; \mathrm{p}=0.008\right)$. The time necessary for recruits to reach the adult size here proposed ( $9.4 \mathrm{~mm} \mathrm{CL}$ ) was estimated as 85 and 95 days for males and females, respectively.

\section{DISCUSSION}

In our study, we observed that females reached larger sizes than males, which was previously observed for the same species by Costa and Fransozo (2004a) in the Ubatuba region and by Garcia et al. (2016) in the Cananéia region, as well as in studies of other penaeoid shrimps (Semensato and Di Beneditto 2008, Castilho et al. 2008a, b, 2015b, Grabowski et al. 2014, 2016). Such sexual dimorphism is considered a general rule among penaeids (Boschi 1989), indicating a likely adaptation to increase egg production (Gab-Alla et al. 1990, Yamada et al. 2007). In addition, Simões et al. (2013), studying Acetes americanus Ortmann, 1893, also found such differential growth between the sexes. Such growth differences thus occur in both superfamilies included in the Dendrobranchiata (Penaeoidea and Sergestoidea).

The theory purposed by Fisher (1930) states that gonochoristic species present equal abundances between the sexes, which runs counter to the results of Wenner (1972) in which several crustacean species show exceptions to this pattern. Recent studies carried out along the Brazilian coast also run counter to Fisher's (1930) theory, including Sicyonia dorsalis Kingsley 1878 (Castilho et al. 2008a), A. longinaris (Castilho et al. 2007a, 2015b), P. muelleri (Castilho et al. 2008b) and X. kroyeri (Castilho et al. 2015a, Grabowski et al. 2014, 2016). In this study, $R$. constrictus constitutes an exception to Fisher's (1930) theory and also agrees with previous studies carried out on the species (Costa and Fransozo 2004a, Garcia et al. 2016).

Deviations from a 1:1 sex ratio can be a result of the interaction of countless factors, such as differential growth rates, migration patterns and mortality rates between the sexes (Wenner 1972). In addition, certain growth parameters (higher growth coefficient and lower asymptotic length in males) can induce female-biased sex ratios (Simões et al. 2013). Garcia et al. (2016) also observed 


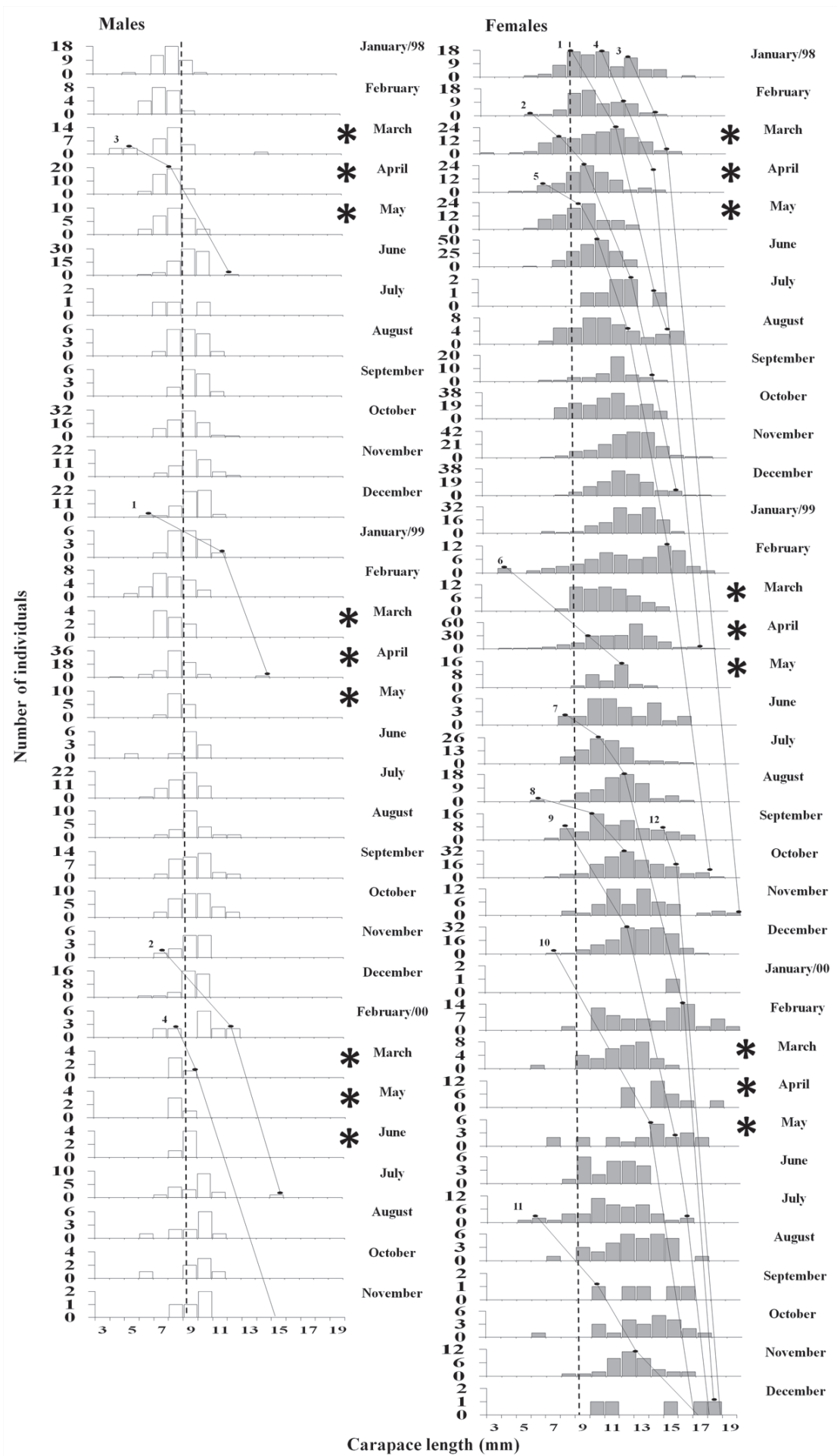

Figure 4 - Rimapenaeus constrictus. Selected cohorts (lines) for growth analyses performed on data sampled from January 1998 to December 2000 at the Northern littoral of São Paulo state. Dotted lines: recruitment size (9.4 mm CL); *: periods in which shrimpfishing activities are prohibited by the responsible federal environmental agency. 


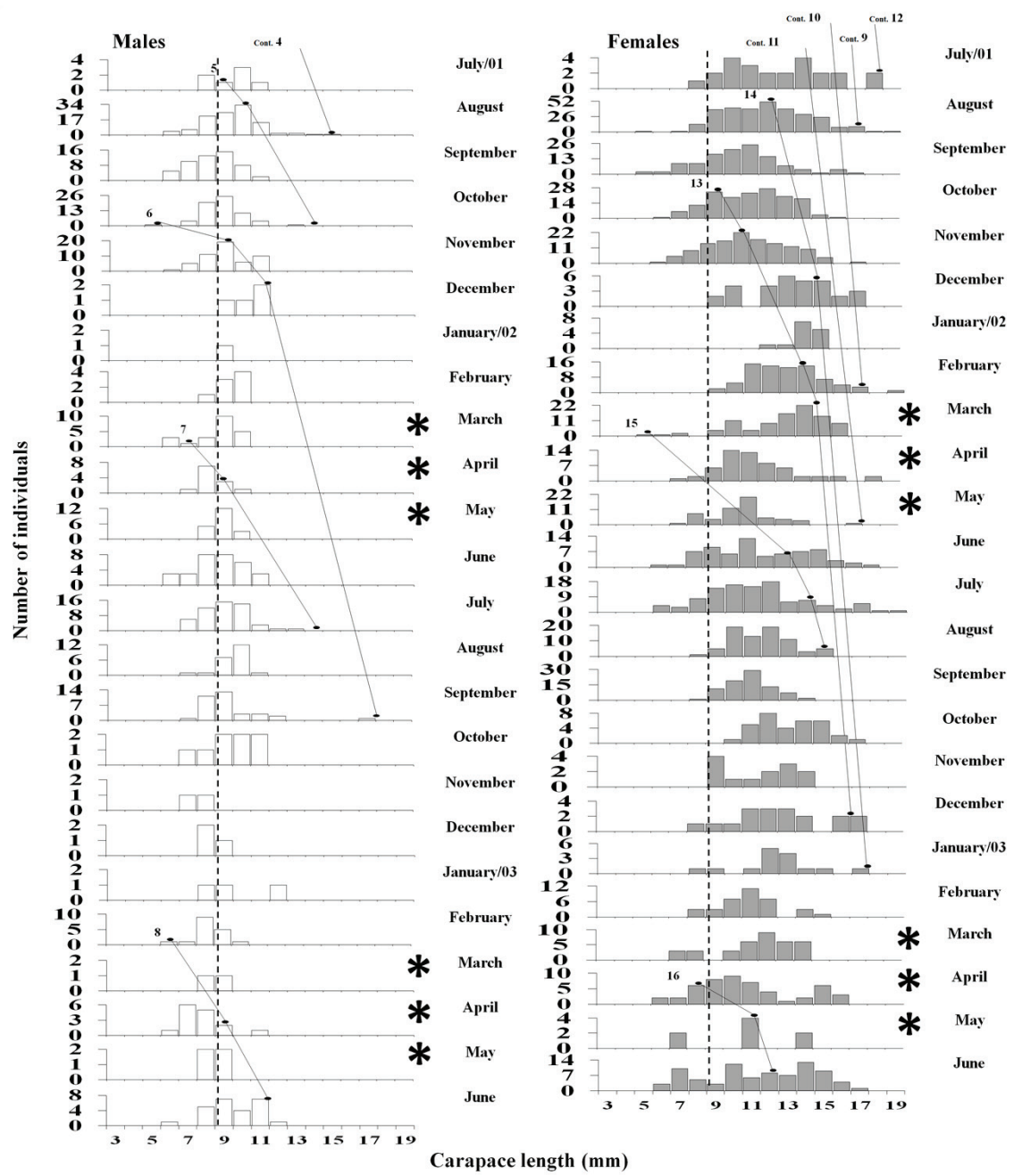

Figure 5 - Rimapenaeus constrictus. Selected cohorts (lines) for growth analyses performed on data sampled from July 2001 to June 2003 at the Northern littoral of São Paulo state. Dotted lines: recruitment size $(9.4 \mathrm{~mm} \mathrm{CL})$; *: periods in which shrimp-fishing activities are prohibited by the responsible federal environmental agency.

female-biased sex ratios for $R$. constrictus, as in our study. According to the authors, the femalebiased sex ratios in higher size classes can also be a consequence of the lower longevity observed for males.

The longevity observed in wild animals is highly variable and may be equal for both sexes of certain species or even differ between them (Vogt 2012). However, it is quite common to observe penaeoid males showing a lower longevity than females, as previously described in the literature (Simões et al. 2013, Grabowski et al. 2014, Castilho et al. 2015a, b) and as observed in our results. Vogt (2012) pointed out some factors that can influence the discrepancy observed in this parameter, such as geographical latitude, habitat, differences in mortality rates, energy costs of reproduction, and hormonal issues. Additionally, penaeoid males generally present a higher growth coefficient $(k)$ and consequently a lower asymptotic length $\left(C L_{\infty}\right)$ (Garcia and Le Reste 1986, Boschi 1969, Petriella and Boschi 1997), as well as lower longevity (Castilho et al. 2012). 


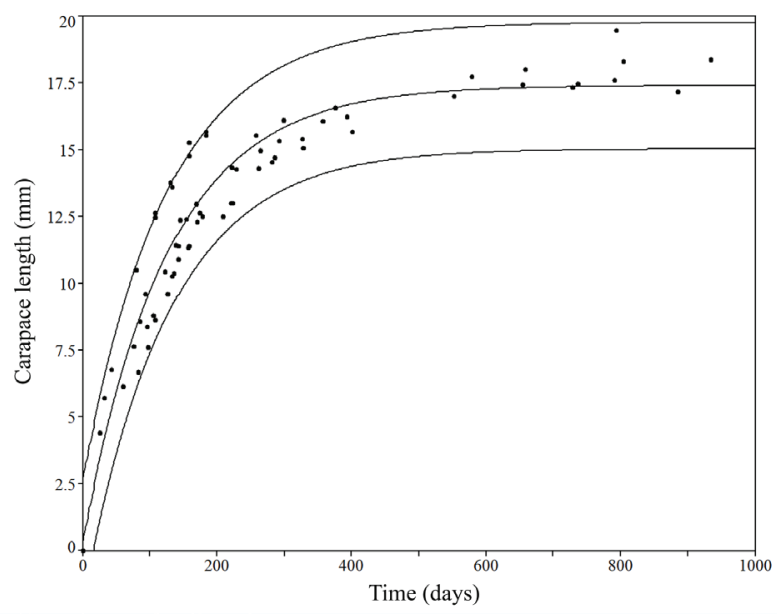

Figure 6 - Rimapenaeus constrictus. Mean estimated growth curve based on the von Bertalanffy growth model for females sampled from July 1998 to June 2003 in the Ubatuba region, northern São Paulo state. Outer lines: 95\% prediction intervals.

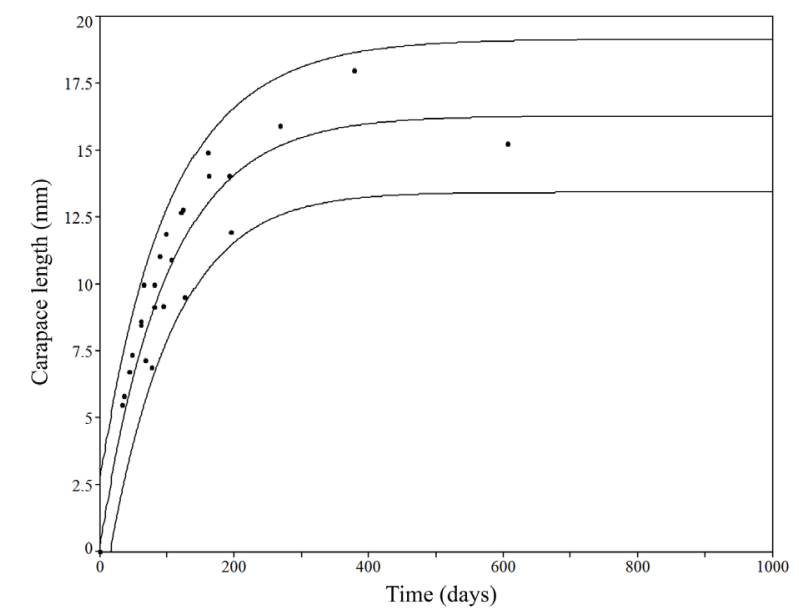

Figure 7 - Rimapenaeus constrictus. Mean estimated growth curve based on the von Bertalanffy growth model for males sampled from July 1998 to June 2003 in the Ubatuba region, northern São Paulo state. Outer lines: 95\% prediction intervals.

Garcia et al. (2016) propose that the lower longevity (and consequent lower asymptotic length) of males is due to their higher metabolic rate, which leads to a cellular senescence induced by the higher investment in the growth rate (a higher $k$ than for the females). This could also explain the tendency for males to show higher mortality rates compared to females (Gab-Alla et al. 1990). We therefore propose that the lower longevity of males is the main reason for the female-biased sex ratio, even though we do not discard the possible influence of other factors. Among them, are the higher susceptibility of females to sampling gear as a function of their search for food during the period of ovary maturation (Kevrekidis and ThessalouLegaki 2006), migratory activities, and differential habitat occupation (Wenner 1972), among others.

Many studies have observed that some marine crustaceans can experience differential environmental influences at latitudinal scales that can impact their life history parameters (Castilho et al. 2015a, Garcia et al. 2016). Bauer (1992) and Castilho et al. (2007b) state that penaeoid life history aspects such as longevity and size at the onset of sexual maturity can vary according to the environmental conditions related to latitude, such as water temperature and nutrient availability. According to this "latitudinal effect paradigm", in subtropical and temperate regions, individuals tend to exhibit a slower growth rhythm and a higher longevity, likely influenced by the lower water temperatures found in these areas (Bauer 1992).

To date, Garcia et al. (2016) have provided the only available data on $R$. constrictus growth estimates carried out on the Brazilian Coast. This study, carried out in the Cananéia region at higher latitudes values $\left(25^{\circ} \mathrm{S}\right)$ than Ubatuba, reports lower asymptotic lengths (females: 16.40 $\mathrm{mm}$; males: $11.74 \mathrm{~mm}$ ), longevities (females: 415 days [1.14 year]; male: 267 days [0.73 year]) and growth coefficients (females: 0.011; males: 0.017 ) compared to our results, suggesting that the latitudinal effect paradigm is not applicable to this species' population dynamics between these two regions.

To comprehend this scenario, it is necessary to keep in mind that physical processes influence the biological ones (Castro-Filho et al. 1987). Cananéia (southern littoral) and Ubatuba (northern littoral) show distinct physical features and thus have distinct biological processes. We propose, 
therefore, that uncountable factors related to the peculiar features of the Ubatuba region (different from Cananéia) influenced the biological processes in different ways and intensities, resulting in such exceptions to the latitudinal pattern. We propose three possible factors that can be held responsible for such a situation, which are listed below.

The first of these, typical of Ubatuba, is the water temperature, which is strongly molded by water masses such as the SACW which approaches the coastal zone during late spring and early summer, causing a decrease in bottom water temperature $\left(<18^{\circ} \mathrm{C}\right)$ and salinity $(<36)$ (CastroFilho et al. 1987). According to Mantelatto and Fransozo (1999), the approaching SACW exerts a strong influence on the water temperature close to the bottom and causes considerable changes in the local communities. The SACW-induced low water temperatures possibly influence the environmental patterns so that Ubatuba presents subtropical rather than tropical environmental features (since shrimp seem to grow more slowly, reach larger sizes, and live longer).

Bauer (1992) points out that some taxa may have planktotrophic larvae, which are affected by very different pressures in the plankton (oscillations in the food supply and predators, for instance) that may influence larval success and recruitment in a variety of ways. Thus, the second factor is based on the statement by Vega-Pérez (1993) asserting that during the approaching SACW the chlorophyll values are higher due to an increase in phytoplankton production, confirming the tendency for water enrichment along the continental shelf during summer (Castro-Filho et al. 1987). Therefore, we propose here that the amount of nutrients in the water column might also have influenced the life history parameters observed in this study. Because the SACW may provide an important source of nutrients and allow a greater larval success, it also makes sense that individuals would be able to reach greater sizes and longevities.
The third and last proposed influencing factor is the type of sediment found in this region, which was characterized by Mantelatto and Fransozo (1999) and shown to be composed mainly of very coarse, coarse, and medium sand. This type of sediment favors not only a higher retention of organic matter content (a possible food resource) but also favors this species' common burrowing behavior. Such behavior may play a fundamental role in the defense of these organisms against predators (Dall et al. 1990), which could also correspond to a higher longevity. According to Negreiros-Fransozo et al. (1991), the distribution of different types of sediment is controlled by water currents. The sinuous littoral observed in Ubatuba (Ab'Sáber 1955) provides great barriers to the entry of seawater, possibly decreasing the intensity with which currents approach this region, which would stir the sediment, forcing animals to emerge and making them more susceptible to capture and predation.

Castilho et al. (2015b) observed that the geographical proximity between regions could establish migratory connections between groups that are part of the same population. However, despite the latitudinal proximity between Cananéia $\left(23^{\circ} \mathrm{S}\right)$ and Ubatuba $\left(25^{\circ} \mathrm{S}\right)$, we strongly suggest that the peculiar oceanographic conditions from Ubatuba (particularly, the above-mentioned effects of the SACW) produced the factors that most likely led to the exceptions.

Several studies carried out with different penaeoidean species suggest the necessity for adaptations to the fisheries closure period. Studies on P. muelleri, $X$. kroyeri and A. longinaris (Castilho et al. 2012, 2015a, b, respectively) show only 1,11 and 2 growth curves protected in the fisheries closure seasons, from 15, 37 and 14 curves, respectively. We also observed that most of the recruitment cohorts do not arise during the months included in the closed fishery period (see figs. 5 and 6), thus strengthening this idea. Thus, 
it is reasonable to infer that the highest efficiency for protecting the species would be realized with an adaptation to the fisheries closure period in the months in which we can observe recruitment cohorts. Therefore, we propose here that the shrimp fishing closed season include late spring and early summer (from December to February) in addition to the already established closed months (March to May).

On the other hand, it is comprehensible that increasing the number of months covered by the fisheries closure period could induce social and economic issues (Castilho et al. 2015a). It is important to remember that the fishery activity is an essential source of income, employment and livelihood for millions of families, which are partially or totally dependent on it. Therefore, Castilho et al. (2015a) suggest further migration studies concerning the locations of the main stocks of reproductive and recruitment individuals in different areas. These data could be crucial for determining the zones and periods of total fishery prohibition, protecting not only the economically important species, but also the bycatch taxa. Additionally, Silva et al. (2013) attest that the management effectiveness of the shrimp fishery is not only achieved by closed fishing seasons, but also by the number of fishing licenses issued, the engine size and dimensions of fishing vessels, minimum mesh sizes and other characteristics as well.

We can infer that $R$. constrictus completes its ontogeny in the studied region since we sampled individuals in a wide range of size classes from juveniles to adults. We strongly believe that the growth coefficient was directly related to the longevity of the individuals and that the growth parameters ran counter to the expected latitudinal effect paradigm, likely in response to the environmental conditions observed in Ubatuba. The present study provides information of undoubted relevance to the field of fishing management, since we present a basis for the establishment of sustainable capture policies. On the basis of such results, therefore, we strongly recommend that the fisheries closure period be changed to protect this species' recruitment period and, consequently, also its adult individuals. It is important to keep in mind that scientifically based knowledge is indispensable for protecting with greater efficiency the ecologically important stocks and avoiding their collapse in the near future. To achieve excellence in such activities, it is crucial to support additional studies at a wide geographical scale in order to understand the influence of latitudinal variations in the growth dynamics of this species.

\section{ACKNOWLEDGMENTS}

We thank many colleagues from the NEBECC group who helped with sampling and laboratory analyses; and the Instituto Brasileiro do Meio Ambiente e dos Recursos Naturais Renováveis (IBAMA) for granting permission to collect the shrimps. This work was supported by Fundação de Amparo à Pesquisa do Estado de São Paulo (FAPESP) (Biota \# 98/07090-3, \# 2010/501888; Scholarships \# 97/12106-8, \# 07/56733-5, \# 2015/13639-5); Coordenação de Aperfeiçoamento de Pessoal de Nível Superior - Ciências do Mar (CAPES-CIMAR) (\#23038.004310/2014-85) and Conselho Nacional de Desenvolvimento Científico e Tecnológico (CNPq) (Research Scholarships PQ \# 305919/2014-8; PQ 308653/2014-9).

\section{REFERENCES}

AB'SÁBER AN. 1955. Contribuição à geomorfologia do litoral paulista. Rev Bras Geogr 17: 3-48.

BAUER RT. 1992. Testing generalizations about latitudinal variation in reproduction and recruitment patterns with sicyoniid and caridean shrimp species. Invertebr Reprod Dev 22: 193-202.

BAUER RT AND LIN J. 1994. Temporal patterns of reproduction and recruitment in populations of the penaeid shrimps Trachypenaeus similis (Smith) and T. constrictus 
(Stimpson) (Crustacea: Decapoda) from the Northcentral Gulf of Mexico. J Exp Mar Biol Ecol 182: 205-222.

BAUER RT AND RIVERA VEGA LW. 1992. Pattern of reproduction and recruitment in two sicyoniid shrimp species (Decapoda: Penaeoidea) from a tropical seagrass habitat. J Exp Mar Biol Ecol 161: 223-240.

BOSCHI EE. 1969. Crecimiento, migración y ecología del camarón comercial Artemesia longinaris Bate de Mar del Plata. FAO Fish Rep 57: 833-846.

BOSCHI EE. 1989. Biología pesquera del langostino del litoral patagonico de Argentina (Pleoticus muelleri). Inst Nac Invest Desarr Pesq 646: 5-71.

CAMPOS BR, BRANCO JO AND D'INCAO F. 2011. Crescimento do camarão-sete-barbas (Xiphopenaeus kroyeri (Heller 1862)), na Baía de Tijucas, Tijucas, SC (Brasil). Atlântica 33: 201-208.

CASTILHO AL, BAUER RT, FREIRE FAM, FRANSOZO V, COSTA RC, GRABOWSKI RC AND FRANSOZO A. 2015a. Lifespan and reproductive dynamics of the commercially important sea bob shrimp Xiphopenaeus kroyeri (Penaeoidea): synthesis of a 5-year study. J Crust Biol 35: 30-40.

CASTILHO AL, COSTA RC, FRANSOZO A AND BOSCHI EE. 2007a. Reproductive pattern of the South American endemic shrimp Artemesia longinaris (Decapoda: Penaeoidea), off São Paulo state, Brazil. Rev Biol Trop 55: 39-48.

CASTILHO AL, COSTA RC, FRANSOZO A AND NEGREIROS-FRANSOZO ML. 2008b. Reproduction and recruitment of the South American red shrimp, Pleoticus muelleri (Crustacea: Solenoceridae), from the Southeastern coast of Brazil. Mar Biol Res 4: 361-368.

CASTILHO AL, FURLAN M, COSTA RC AND FRANSOZO V. 2008a. Reproductive biology of the rock shrimp Sicyonia dorsalis (Decapoda: Penaeoidea) from the southeastern coast of Brazil. Invertebr Reprod Dev 52: 59-68.

CASTILHO AL, GAVIO MA, COSTA RC, BOSCHI EE, BAUER RT AND FRANSOZO A. 2007b. Latitudinal variation in population structure and reproductive pattern of the endemic South American shrimp Artemesia longinaris (Decapoda: Penaeoidea). J Crust Biol 27: 548552.

CASTILHO AL, GRABOWSKI RC, SIMÕES SM, SANTOS APF, COSTA RC AND FRANSOZO A. 2015b. Lifespan and population dynamics of the endemic South American shrimp Artemesia longinaris (Crustacea: Penaeidae) in southeastern Brazil. An Acad Bras Cienc 87: 2123-2138.

CASTILHO AL, WOLF MR, SIMÕES SM, BOCHINI GL, FRANSOZO V AND COSTA RC. 2012. Growth and reproductive dynamics of the South American red shrimp, Pleoticus muelleri (Crustacea: Solenoceridae), from the southeastern coast of Brazil. J Mar Syst 105-108: 135-144.
CASTRO-FILHO BM, MIRANDA LB AND MIYAO SY. 1987. Condições hidrográficas na plataforma continental ao largo de Ubatuba: variações sazonais e em média escala. Bol Inst Oceanogr 35: 135-151.

CERRATO RM. 1990. Interpretable statistical tests for growth comparisons using parameters in the von Bertalanffy equation. Can J Fish Aquat Sci 47: 1416-1426.

COSTA RC AND FRANSOZO A. 2004a. Reproductive biology of the shrimp Rimapenaeus constrictus (Decapoda, Penaeidae) in the Ubatuba Region of Brazil. J Crust Biol 24: 274-281.

COSTA RC AND FRANSOZO A. 2004b. Abundance and ecologic distribution of the shrimp Rimapenaeus constrictus (Crustacea: Penaeidae) on the northern coast of São Paulo State, Brazil. J Nat Hist 38(7): 901-912.

DALL W, HILL BJ, ROTHLISBERG PC AND SHARPLES DJ. 1990. The Biology of the Penaeidae. In: Blaxter JHS and Southward AJ (Eds), Advances in Marine Biology. San Diego: Academic Press, 489 p.

DIAS NETO J. 2011. Proposta de plano nacional de gestão para o uso sustentável de camarões marinhos do Brasil. Brasília: Instituto Brasileiro do Meio Ambiente e dos Recursos Naturais Renováveis e Ministério do Meio Ambiente. IBAMA 59(1): 242.

D'INCAO F AND FONSECA DB. 1999. Performance of the von Bertalanffy growth curve in penaeid shrimps: a critical approach. In: von Vaupel Klein JC and Schram FR (Eds), The Biodiversity Crisis and Crustacea: Proceedings of the Fourth International Crustacean Congress. Amsterdam (The Netherlands), Brill Academic Publishers, Leiden, The Netherlands, p. 733-737.

D'INCAO F, VALENTINI H AND RODRIGUES LF. 2002. Avaliação da pesca de camarões nas regiões Sudeste e Sul do Brasil. Atlântica 24: 103-116.

FAO - FOOD AND AGRICULTURE ORGANIZATION OF THE UNITED NATIONS. 2015. Transforming wasted resources for a sustainable future. The sustainable management of bycatch in Latin America and Caribbean trawl fisheries. Fisheries and Aquaculture Department, 8 p.

FISHER RA. 1930. The genetical theory of natural selection. New York Dover Publications, 318 p.

FONSECA DB AND D'INCAO F. 2003. Growth and reproductive parameters of Kalliapseudes schubartii in the estuarine region of the Lagoa dos Patos (southern Brazil). J Mar Biol Ass UK 5: 931-935.

GAB-ALLA AAFA, HARTNOLL RG, GHOBASHY AF AND MOHAMMED SZ. 1990. Biology of penaeid prawns in the Suez Canal lakes. Mar Biol 107: 417-426.

GARCIA JR, WOLF MR, COSTA RC AND CASTILHO AL. 2016. Growth and reproduction of the shrimp Rimapenaeus constrictus (Decapoda: Penaeidae) from the southeastern coast of Brazil. Reg Stud Mar Sci 6: 1-9. 
GARCÍA S AND LE RESTE L. 1986. Ciclos vitales, dinámica, explotación y ordenación de las poblaciones de camarones peneidos costeros. FAO Doc Téc Pesca 203: 180.

GRABOWSKI RC, NEGREIROS-FRANSOZO ML AND CASTILHO AL. 2016. Reproductive ecology of the seabob shrimp Xiphopenaeus kroyeri (Heller, 1862) in a coastal area of Southern Brazil. Chin J Oceanol Limnol 34: 125-135.

GRABOWSKI RC, SIMÕES SM AND CASTILHO AL. 2014. Population structure, sex ratio and growth of the seabob shrimp Xiphopenaeus kroyeri (Decapoda, Penaeidae) from coastal waters of southern Brazil. In: Wehrtmann IS and Bauer RT (Eds), Proceedings of the Summer Meeting of the Crustacean Society and the Latin American Association of Carcinology, Costa Rica. ZooKeys 457: 253-269.

HARTNOLL RG. 2001. Growth in Crustacea - twenty years on. Hydrobiologia 449: 111-122.

HIROKI KAN, FRANSOZO A, COSTA RC, CASTILHO AL, SHIMIZU RM, ALMEIDA AC AND FURLAN M. 2011. Bathymetric distribution of the shrimp Rimapenaeus constrictus (Stimpson, 1874) (Decapoda, Penaeidae) in two locations off the southeastern Brazilian coast. Mar Biol Res 7: 176-185.

IBAMA - INSTITUTO BRASILEIRO DO MEIO AMBIENTE E DOS RECURSOS NATURAIS RENOVÁVEIS. 2016. $<$ www.ibama.gov.br > . Acesso em Maio de 2016.

KEVREKIDIS K AND THESSALOU-LEGAKI M. 2006. Catch rates, size structure and sex ratio of Melicertus kerathurus (Decapoda: Penaeidae) from an Aegean Sea trawl fishery. Fish Res 80: 270-279.

KING M. 1995. Fisheries biology, Assessment and Management. Fishing News Books, Oxford, UK, 341p.

MANTELATTO FLM AND FRANSOZO A. 1999. Characterization of the physical and chemical parameters of Ubatuba Bay, northern coast of São Paulo state, Brazil. Rev Bras Biol 59: 23-31.

NEGREIROS-FRANSOZO ML, FRANSOZO A, PINHEIRO MAA, MANTELATTO FLM AND SANTOS S. 1991. Caracterização Física e Química da Enseada de Fortaleza, Ubatuba, SP. Rev Bras Geociênc 21: 114-120.

PÉREZ-FARFANTE I. 1988. Illustrated key to Penaeoid shrimps of commerce in the Americas. NOAA Tech Rep NMFS 64: 1-32.
PÉREZ-FARFANTE I AND KENSLEY B. 1997. Penaeoid and Sergestoid shrimps and prawns of the World. Keys and diagnoses for the families and genera. Paris, Éditions du Muséum National d Histoire Naturalle, 233 p.

PETRIELLA AM AND BOSCHI EE. 1997. Crecimiento en crustáceos decápodos: resultados de investigaciones realizadas en Argentina. Investig Mar 25: 135-157.

PIRES-VANIN AMS. 2001. Identifying the components of ecological variation in a marine benthic megafauna. Rev Bras Oceanogr 49: 29-38.

SEMENSATO XEG AND DI BENEDITTO APM. 2008. Population dynamic and reproduction of Artemesia longinaris (Decapoda, Penaeidae) in Rio de Janeiro State, South-Eastern Brazil. Bol Inst Pesca 34: 89-98.

SILVA CNS, BROADHURST MK, MEDEIROS RP AND DIAS JH. 2013. Resolving environmental issues in the southern Brazilian artisanal penaeid-trawl fishery through adaptive co-management. Mar Pol 42: 133-141.

SIMÕES SM, D'INCAO F, FRANSOZO A, CASTILHO AL AND COSTA RC. 2013. Sex ratio, growth and recruitment of the pelagic shrimp Acetes americanus on the southeastern coast of Brazil. J Crust Biol 33: 1-9.

SOARES-GOMES A AND PIRES-VANIN AMS. 2003. Padrões de abundância, riqueza e diversidade de moluscos bivalves na plataforma continental ao largo de Ubatuba, São Paulo, Brasil: uma comparação metodológica. Rev Bras Zool 20: 717-725.

VEGA-PÉREZ LA. 1993. Estudo do zooplâncton da região de Ubatuba, Estado de São Paulo. Publ Esp Inst Oceanogr 10: $65-84$.

VOGT G. 2012. Ageing and longevity in the Decapoda (Crustacea): A review. Zool Anz 251: 1-25.

VON BERTALANFFY L. 1938. A quantitative theory of organic growth. Human Biology 10: 181-213.

WENNER AM. 1972. Sex ratio as a function of size in marine crustacean. Am Nat 106: 321-350.

WILSON K AND HARDY ICW. 2002. Statistical analysis of sex ratio: an introduction. In: Hardy ICW (Ed), Sex ratios: concepts and research methods. Cambridge University Press, Cambridge, p 48-92.

YAMADA R, KODAMA K, YAMAKAWA T, HORIGUCHI T AND AOKI I. 2007. Growth and reproductive biology of the small penaeid shrimp Trachysalambria curvirostris in Tokyo Bay. Mar Biol 151: 961-971. 